\title{
Factors Affecting Usage Intention of Mobile Banking: Empirical Evidence from Turkey ${ }^{1}$
}

\author{
Aytaç ERDEM iD a Ufuk PALA iD b Mustafa ÖZKAN iD c Uğur SEVİM iD d \\ a Giresun University, Giresun, Turkey. aytacerdem54@hotmail.com \\ b Giresun University, Giresun, Turkey.palaufuk@yahoo.com \\ cGiresun University, Giresun, Turkey. mstf.ozknn@hotmail.com \\ d Giresun University, Giresun, Turkey. ugursevim@yahoo.com
}

\begin{tabular}{ll}
\hline ARTICLE INFO & ABSTRACT \\
\hline Keywords: & $\begin{array}{l}\text { Purpose - Even conventional banking transactions were hard to leave for } \\
\text { bank cus-tomers, due to the convenience of mobile banking, banking technologies }\end{array}$ \\
Mobile Banking & have changed dramatically. Mobile banking technology adoption was late in \\
Trust, Service Quality & Turkey; however it showed a much more rapid progress in comparison with \\
Perceived Risk & developed countries. In this study, it is aimed to examine the effect of trust and \\
Perceived Benefit & service quality on mobile banking usage intention. Also, the effect of usage \\
& intention on perceived risk and benefit is in-tended to reveal. \\
Received 8 July 2019 & Design/methodology/approach - The data is collected from the individuals \\
Revised 17 October & who benefit from the banking services in Turkey. Bank customers who live in \\
Accepted 25 October & different regions of Turkey constitute the sample of the study. The research data \\
& was collected by survey and convenience sampling is used as a sampling method. \\
& $\begin{array}{l}\text { Structural Equation Modeling has been used as a research method and data were } \\
\text { tested in terms of validity and reliability through data confirmatory factor analysis. }\end{array}$ \\
Article Classification: & $\begin{array}{l}\text { Results - Research findings revealed that trust and quality factors are } \\
\text { Research Article }\end{array}$ \\
highly associ-ated with intention to use mobile banking. Furthermore, intention \\
to use decreases the perceived risk and increases the perceived \\
benefit. Discussion - Banks should pay attention on mobile banking security \\
system to increase the number of mobile banking users. Also, service quality such \\
as ease-of-use, visual appeal and information relevancy helps them to create \\
mobile banking usage intention. Moreover, customers mobile banking usage \\
intention has an impact on perceived ben-efit and perceived risk that it lessens \\
perceived risk and increases perceived benefit.
\end{tabular}

${ }^{1}$ Extended summary of this paper is published in Global Conference on Business And Economics Conference book Suggested Citation

Erdem, A., Pala, U., Özkan, U., Sevim, U. (2019). Factors Affecting Usage Intention of Mobile Banking: Empirical Evidence from Turkey, Journal of Business Research-Turk, 11 (4), 2384-2395 
A. Erdem - U. Pala - M. Özkan - U. Sevim 11/4 (2019) 2384-2395

\section{Introduction}

Nowadays, due to the rapid changes in science and technology, financial institutions, enterprises and banks have to adapt to this change and give importance to technology. Rapid developments in these areas have been influential on the finance and banking sector as well as in all fields related to economy.

After the 1960s, with the developments in technology, products such as lane calculator, paperpen and typewriter used in the banking sector were first replaced by computers. And after the 2000s, in addition to computers, new generation devices such as mobile phones, tablets etc. have become new devices used by banks and customers for banking transactions. The widespread use of technology has made it compulsory for the banking sector to make use of technology and the electronic banking period has started in the banking sector. Through electronic banking services all kinds of monetary transactions are offered to customers without time and space restriction.

Today, banking sector undergoes a transform from classic banking to electronic banking approach by investing heavily in Information Technologies. In this context, because of the above mentioned developments, the most prominent concepts have become internet banking and mobile banking.

Mobile banking is defined as a mobile information processing application which gives customers opportunity to make banking transactions anywhere and at any time via Smartphone. This system removes time and place limitations while making transactions like checking the banking accounts or transferring money between accounts.

When the development of mobile banking technologies is examined, it is noteworthy to express that such technologies have been rapidly adopted all over the world. One of the best examples in terms of understanding this development is Turkey. Despite the fact that Turkey was relatively late to integrate mobile banking technology in comparison to similar countries, it showed a much more rapid progress in Turkey. In this sense, it will be useful to examine Turkey in terms of explaining the mobile banking adoption factors.

Mobile banking statistics of Turkey has been held through the Banks Association of Turkey (TBB) regularly since 2011 . When the related statistics published by TBB are analyzed, it can be seen that shortly mobile banking in Turkey has attracted a significant demand. So that, the number of customers registered in the system in order to carry out mobile banking and made at least one entry transaction is approximately 1 million 274 thousand people in Turkey. 446 of these customers (35 percent) have entered at least once during October-December 2011 period. The volume of 376 thousand investment transactions realized with mobile banking in the period of OctoberDecember 2011 was 1,494 million TL. In the same year, total financial transactions excluding investment transactions through mobile banking were realized as 2.2 million transactions and was amounted as 2.5 billion TL. When the transaction types carried out through mobile banking are analyzed, it is seen that the money transfer transactions including EFT, money order transfer and foreign exchange transfer transactions constitute 86 percent of the financial transaction volume other than investment transactions. 

A. Erdem - U. Pala - M. Özkan - U. Sevim 11/4 (2019) 2384-2395

As it can be seen from Table 1, It is noteworthy that 44 million 851 thousand customers (both individual and corporate customers) registered in mobile banking system and made at least one entry transaction between October-December 2017.29 million 541 thousand people (66 percent) includes customers who logged in once in the last 3 months during October-December 2017 period. In this sense, the number of registered customers of mobile banking show a dramatic increase in Turkey that there is an increase from 1 million 274 thousand people to 44 million 851 thousand people between the years 2011 and 2017. A similar increase is also observed in the number of active customers. The Table 1 below includes information about the number of mobile banking customers in Turkey for the year 2017.

Table 1: Number of Mobile Banking Customers

\begin{tabular}{|c|c|c|}
\hline & $\begin{array}{l}\text { July-September } \\
2017\end{array}$ & $\begin{array}{l}\text { October-December } \\
2017\end{array}$ \\
\hline \multicolumn{3}{|l|}{ Customers (Individual-thousand people) } \\
\hline Active $(X)$ & 25.788 & 28.712 \\
\hline Registered (Y) & 39.395 & 43.436 \\
\hline Registered (Z) & 31.954 & 35.227 \\
\hline $\begin{array}{l}\text { The ratio of customer [Active }(X) / \text { registered } \\
\text { (Y)] }\end{array}$ & 65 & 66 \\
\hline \multicolumn{3}{|l|}{ Customers (Corporate-thousand people) } \\
\hline Active $(X)$ & 748 & 829 \\
\hline Registered $(\mathrm{Y})$ & 1.286 & 1.415 \\
\hline Registered (Z) & 972 & 1.067 \\
\hline $\begin{array}{l}\text { The ratio of customer [Active }(\mathrm{X}) / \text { registered } \\
\text { (Y)] }\end{array}$ & 58 & 59 \\
\hline \multicolumn{3}{|l|}{ Customers (Total-thousand people) } \\
\hline Active $(X)$ & 26.536 & 29.541 \\
\hline Registered (Y) & 40.681 & 44.851 \\
\hline Registered (Z) & 32.926 & 36.295 \\
\hline $\begin{array}{l}\text { The ratio of customer [Active }(\mathrm{X}) / \text { registered } \\
\text { (Y)] }\end{array}$ & 65 & 66 \\
\hline \multicolumn{3}{|c|}{$\begin{array}{l}\mathrm{X} \text { : logged in once in the last } 3 \text { months, } \mathrm{Y}: \text { has logged in at least once, } \mathrm{Z} \text { : logged in at least once } \\
\text { in the last } 1 \text { year }\end{array}$} \\
\hline \multicolumn{3}{|l|}{ Source: Türkiye Bankalar Birliği (TBB)(www.tbb.org.tr) } \\
\hline \multicolumn{3}{|c|}{$\begin{array}{l}\text { When it is evaluated from the point of view of operations carried out through mobile banking, } 18 \\
\text { million investment transactions were carried out with mobile banking in the period of October- } \\
\text { December } 2017 \text { and the volume of the said transactions was } 200 \text { billion TL. In the same period, } \\
\text { the total amount of financial transactions made using mobile banking service was } 280 \text { million and } \\
\text { the amount was } 644 \text { billion TL. Again, compared to the year 2011, in terms of the transaction } \\
\text { amount and volume, it's obvious that there is a serious development. }\end{array}$} \\
\hline
\end{tabular}




\section{A. Erdem - U. Pala - M. Özkan - U. Sevim 11/4 (2019) 2384-2395}

In addition, in terms of the type of transactions carried out via mobile banking, it is observed that the types of transactions carried out show an increase since 2011.In fact that, in 2011, money transfers involving EFT, money order and foreign exchange transactions accounted for 86 percent of the financial transaction volume, and this rate was 58 percent in 2017. The most important reason for this is the increase in financial transaction types through mobile banking. For example, in 2011, when credit utilization via mobile banking was not possible, 581 thousand units and 6 billion 136 thousand TL of instant credit were used via mobile banking only in October-December 2017 period.

In the light of such information, it would become certain to research factors affecting the usage intention of mobile banking in Turkey. Therefore, it is useful to review the literature in order to determine the factors affecting the mobile usage intention.

\section{Literature Review}

Various studies have been carried out that focused on mobile banking in the literature. These papers also examine the factors affecting the mobile banking usage intention. For this purpose; Shaikh and Karjaluoto (2015) studied these factors with the help of the literature research. Mobile banking use of individuals has been investigated in this paper and the results revealed that the most important factor of usage intention of mobile banking is perceived usefulness. These results are valid for both developed and developing countries. Another study in the literature that investigates the adoption intention of mobile banking technology was carried by Püschel et al. (2010). They've collected Brazilian data to examine the mobile banking adoption intention of individuals. According to the results of their study, factors that affect the attitudes of Brazilian customers towards mobile banking are relative advantage, compatibility and enriching the customer's intention to adopt mobile banking. Malaquias and Hwang (2016) studied the trust factor in the framework of mobile banking technology. This study investigates the trust factor from the viewpoint of developing countries. The results of the study show that having no trust has a negative effect on the use of mobile banking. Data collected for the study is only applicable for undergraduate individuals but still it shows that trust factor is an important factor for mobile banking usage. In South Africa, Brown et al. (2003) studied the factors affecting the adoption of mobile banking to help understanding how to increase the adoption rate of mobile banking usage. Although banks have mobile banking technologies in South Africa, customers using mobile banking technology are very rare. As a result of the study, relative advantage, trialability and customers' banking needs have been found as the factors which can help to increase the adoption rate of mobile banking. Another study about mobile banking, Lin's research (2011) is based on examining the adoption intention of mobile banking across the potential and repeat customers. Lin (2011) studied the effect of innovation attributes (perceived relative advantage, ease of use and compatibility) and knowledge-based trust (perceived competence, benevolence and integrity) on adoption of mobile banking intention. According to Lin (2011) this adoption intention is separated into two factors as attitudinal and behavioral. The results indicated that perceived relative advantage, ease of use, compatibility, competence and integrity have an effect on attitudinal adoption, and in turn this leads to behavioral adoption of mobile banking. The concept of continued usage of mobile banking has been investigated by Albashrawi and Motiwalla (2017) in the context of privacy and personalization. Their study has integrated the privacy and personalization context into 


\section{A. Erdem - U. Pala - M. Özkan - U. Sevim 11/4 (2019) 2384-2395}

TAM (Technology Acceptance Model) theoretical model. Data collected from United States' mobile banking users showed that the most important factors for mobile banking customers in United States are perceived usefulness and perceived ease-of-use to be satisfied. Satisfaction of mobile customers in turn leads to continued usage of mobile banking. Also, the privacy factor shows statistical significance but personalization doesn't. A study investigating the mobile banking acceptance of Islamic mobile banking is conducted by Goh and Sun (2014). They have examined the gender differences affecting the Islamic mobile banking acceptance. As a result, perceived self-expressiveness has been found as the most important factor of Islamic mobile banking according to male users and perceived usefulness and social norms have been found as the most important factors between female users. Siddhartha et al. (2011) investigated the factors affecting behavioral intentions towards mobile banking usage in India. They found that, factors like perceived image, perceived value, self-efficacy, perceived credibility and tradition affect have a statistical significance on behavioral intention. Laukkanen and Kiviniemi (2010) examined the effect of information and guidance offered by a bank on five adoption barriers (usage, value, risk, tradition and image). As a result, information and guidance has the most significant effect on decreasing the usage barrier. And they have a significant effect on decreasing image, value and risk barriers respectively. However, information and guidance showed no statistical significance on tradition barrier. Hanafizadeh et al. (2014) built a comprehensive theoretical model to explain adoption of mobile banking. Perceived usefulness, perceived ease of use, need for interaction, perceived risk, perceived cost, compatibility with lifestyle, perceived credibility and trust factors were examined among Iranian customers. As a result, adaptation with lifestyle and trust factors was found as the most significant factors in terms of explaining the mobile banking adoption. Wessels and Drennan (2010), in their study, tried to identify and test the antecedents of mobile banking usage adoption. The results of the study showed that perceived usefulness, compatibility, perceived risk, perceived cost and attitude are found as the most important factors of intention to use mobile banking. Another study conducted by Riquelme and Rios (2010) examined the factors influencing the mobile banking adoption within a Singapore context. They've tested gender as the moderating variable in their study. The results revealed that usefulness, social norms and social risk has a statistically significant effect on mobile banking adoption. Between the female mobile banking customers, ease of use has a stronger effect than male customers and relative advantage has a stronger influence on male customers than the female ones. Besides, social norms have a stronger influence on female customers than the males.

There are a number of studies conducted in Turkey about mobile banking usage. According to a research helded by Korkulu, Oktay and Akan (2018) asserts that age, personal bank loan, credit card usage, internet banking usage, having a bank deposit and ownership of a smartphone or a tablet computer have an impact on the mobile banking usage. The data collected from 398 academic staff indicates that personal bank deposit, credit card usage, ownership of a smartphone or a tablet computer and internet bank usage have a positive impact on mobile banking usage. Another study conducted by Akın and Karaboğa (2011) investigates customers' decision about using branchless banking services. The results of the study show that reliability and qualification have been the most important factors affecting mobile banking usage. Also, in their study, Kurt and Turan (2017) gather data from 288 respondents and found that performance expectation, fa- 


\section{A. Erdem - U. Pala - M. Özkan - U. Sevim 11/4 (2019) 2384-2395}

cilitating conditions, personal innovativeness and trust factors have a significant effect on adoption of mobile banking. As a result of factors derived from the studies in the literature, factors affecting mobile banking usage have been degraded to two factors. Accordingly, trust and service quality are the most important factors which have an impact on mobile banking usage. Unlike other studies conducted in Turkey, this study investigates the impact of usage intention on perceived benefit and perceived risk of mobile banking.

\section{Methodology}

Population of the study consisted of individuals who benefit from the banking services in Turkey. In this context, bank customers living in different regions of Turkey constitute the sample of the study. As a sampling method, convenience sampling which is one of the improbable sampling methods has been used. Convenience sampling method is based on the researcher's random selection of research units and the application of the data collection method in order to collect data from the fastest and least cost way (Nakip, 2013: 271).

The motivation for selecting this sampling method is to present a viewpoint to the users of the banking service, which is the field of application of the research rather than the generalization of the results. The measurement development and hypotheses were based on the earlier literature on mobile banking.

Banking customers need to trust in mobile banking. Problems like viruses or Trojan horses may increase users' concern about payment security and can affect customers' intention to use mobile banking (Zhou, 2011:530). Therefore, examining the trust variable and its effect on usage intention seems very necessary. Besides, lots of studies show a direct significant effect of trust on usage intention (Alalwan et al., 2017; Gu et al., 2009; Hanafizadeh et al., 2014; Kesharwani et al., 2012; Malaquias and Hwang, 2016). In this regard, the following hypothesis is developed:

$\mathbf{H}_{1}$ : Trust is positively associated with intention to use mobile banking.

Another variable affecting the usage intention is quality. Quality reflects the quality of information such as information relevancy, accuracy and timeliness (Kim et al, 2009:294) and quality of services such as ease-of-use, visual appeal etc. (Zhou, 2011:530). If mobile banking systems do not give sufficient information about the transactions or have poor services, this will decrease customers' intention to use mobile banking. Therefore, the following hypothesis is developed:

$\mathbf{H}_{2}$ : Quality is positively associated with intention to use mobile banking

Perceived risk is defined as uncertainty and unfavorable consequences which are related with consumers' expectation (Bauer, 1960). It plays a significant role in many online financial transactions and also in mobile banking transactions (Kesharwani et al., 2012). Perceived risk would affect consumers' actual use of mobile banking in a negative way because of uncertainty. Therefore, if customers' risk perceptions were low, they would be willing to transact. In this regard, it is hypothesized that:

$\mathbf{H}_{3}$ : Intention to use is negatively associated with perceived risk.

In recent studies of mobile banking, it has been suggested that customers buy a product with cognitive and affective evaluation (Kim et al, 2009:288). For this reason, perceived benefit has 
A. Erdem - U. Pala - M. Özkan - U. Sevim 11/4 (2019) 2384-2395

importance in understanding mobile banking (Akturan and Tezcan, 2012). Mobile banking usage intention directly affects perceptions about mobile banking. If usage intention increases, then benefits of mobile banking can be considered as necessary. Therefore, it is hypothesized that:

$\mathbf{H}_{4}$ : Intention to use is positively associated with perceived benefit.

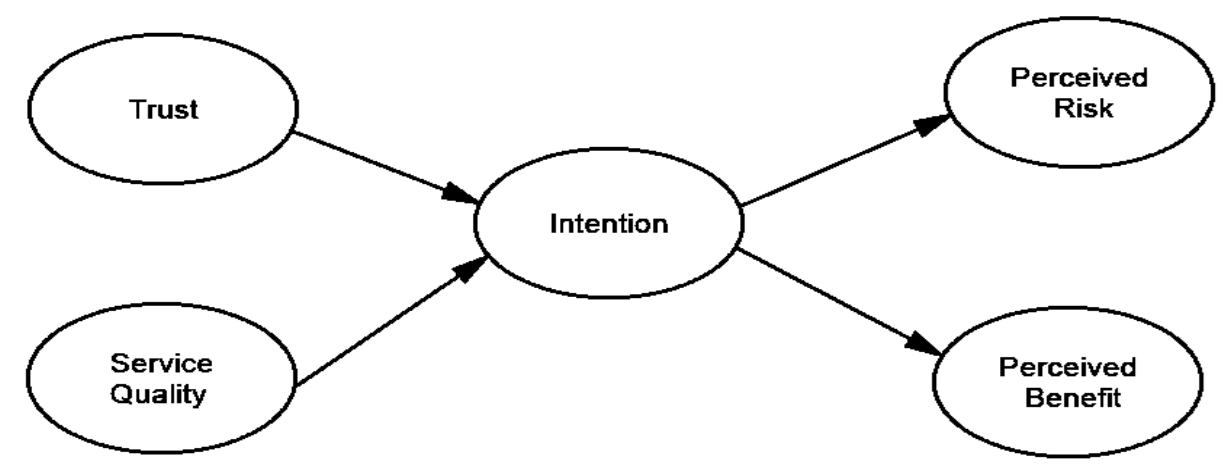

Figure 1: Research Model

\section{Findings}

After we scrutinized all questionnaires, we removed the questionnaires which have too many missing values. As a result, 406 valid responses are obtained. Demographic information of the sample is as follows.

Table 2: The Demographic Information of The Sample

\begin{tabular}{|c|c|c|c|c|c|}
\hline \multirow[t]{2}{*}{ Gender } & \multicolumn{2}{|l|}{ Male } & \multicolumn{3}{|l|}{ Female } \\
\hline & 226 & & 180 & & \\
\hline \multirow[t]{3}{*}{$\begin{array}{l}\text { Income } \\
\text { State }\end{array}$} & $\begin{array}{l}\text { Less than } 500 \\
\text { TL }\end{array}$ & $\begin{array}{l}\text { Between 501- } \\
750\end{array}$ & $\begin{array}{l}\text { Between } \\
751-1000\end{array}$ & $\begin{array}{l}\text { Between } \\
1001-1250\end{array}$ & $\begin{array}{l}1251 \mathrm{TL} \text { and } \\
\text { more }\end{array}$ \\
\hline & & $\mathrm{TL}$ & TL & TL & \\
\hline & 118 & 118 & 82 & 36 & 52 \\
\hline \multirow[t]{2}{*}{ Age } & Less than 20 & $21-30$ & $31-40$ & $41-50$ & 50 and more \\
\hline & 25 & 272 & 58 & 46 & 5 \\
\hline
\end{tabular}




\section{A. Erdem - U. Pala - M. Özkan - U. Sevim 11/4 (2019) 2384-2395}

226 male and 180 female participated in the survey. More than half of the participants (236 out of 406) has a lower income than 750 TL. Participants are between 19 and 61 years old.

Explanatory factor analysis was applied to all the scale items used in the research and since the factor loads were below 0,50 values, some items were subtracted from the trust, quality, and perceived benefit scales. Anderson and Gerbing (1988) approach was followed in the implementation of the Structural Equation Modelling (SEM). Data confirmatory factor analysis is used to test validity and reliability of the data. Not only convergent validity but also discriminant validity was tested. Convergent validity and discriminant validity are subtype of construct validity. While convergent validity measures whether items can effectively reflect their corresponding factor, discriminant validity measures whether two factors are different in terms of statistics. All AVEs exceed 0,5 and all CRs exceed 0,7. Thus the scale has a good convergent validity. Secondly, structural hypothesis were tested with structural equation modeling. The model fitness statistics are shown in Table 3 and the validity and reliability analysis results are given in Table 4 .

Table 3: Summary of Fitness Statistics*

\begin{tabular}{lllllll}
\hline & $\mathrm{Chi}^{2} / \mathrm{df}$ & GFI & AGFI & IFI & CFI & Rmsea \\
\hline Recommended value & $\leq 5$ & $\geq 0,90$ & $\geq 0,80$ & $\geq 0,90$ & $\geq 0,90$ & $\leq 0,08$ \\
$\begin{array}{l}\text { Confirmatory factor } \\
\text { analysis }\end{array}$ & 2,651 & 0,937 & 0,904 & 0,952 & 0,952 & 0,064 \\
$\begin{array}{l}\text { Structural Model } \\
\text { St,335 }\end{array}$ & 0,923 & 0,890 & 0,928 & 0,928 & 0,076 \\
\hline
\end{tabular}

* "Chi $/ \mathrm{df}$ is the ratio between $\mathrm{Chi}^{2}$ and degrees of freedom, GFI is Goodness of Fit Index, AGFI is the Adjusted Goodness of Fit Index, CFI is the Comparative Fit Index, IFI is the Incremental Fit Index, RMSEA is Root Mean Square Error of Approximation."

The relative $\mathrm{Chi}^{2}$ equals the $\mathrm{Chi}^{2}$ index divided by the degrees of freedom. The criterion for acceptance must be less than 5 (Bayram, 2010). The Chi²/df value for confirmatory factor analysis and structural model is acceptable, 2,651 and 3,335 respectively.

GFI (Goodness of Fit Index) shows how the model measures the covariance matrix in the sample (Çokluk, Şekercioğlu ve Büyüköztürk, 2010) and recommending values for GFI must be greater than 0,90 which indicates a good fit. Adjusted Goodness of Fit Index (AGFI) corrects the shortcomings of the GFI in high sample volume (Çapık, 2014: 200). It is generally accepted that values of 0,80 or greater indicate well-fitting models. The IFI (Incremental Fit Index) measures the increase in goodness of fit index compared to the base model. The value greater than 0,90 is acceptable for IFI. CFI (Comparative Fit Index) predicts that there is no relationship between variables. Acceptable rate for CFI is greater than 0,90. The RMSEA show us how well the model, with unknown but optimally chosen parameter estimates would fit the populations covariance matrix (Byrne, 1998) and the value less than 0,08 is acceptable (Bayram, 2010). All fitness indices actualize the conditions (Table 2). 
A. Erdem - U. Pala - M. Özkan - U. Sevim 11/4 (2019) 2384-2395

Table 4: The Validity and Reliability Analysis Results

\begin{tabular}{lccccccccc}
\hline & CR & AVE & MSV & $\operatorname{MaxR}(\mathrm{H})$ & perben & ity & trust & $\begin{array}{l}\text { inten- } \\
\text { tion }\end{array}$ & perrisk \\
\hline perben & 0,728 & 0,573 & 0,570 & 0,737 & $\mathbf{0 , 7 5 7}$ & & & & \\
quality & 0,753 & 0,504 & 0,314 & 0,758 & 0,415 & $\mathbf{0 , 7 1 0}$ & & & \\
trust & 0,824 & 0,540 & 0,426 & 0,826 & 0,388 & 0,558 & $\mathbf{0 , 7 3 5}$ & & \\
intention & 0,885 & 0,721 & 0,570 & 0,897 & 0,755 & 0,560 & 0,498 & $\mathbf{0 , 8 4 9}$ & \\
perrisk & 0,801 & 0,574 & 0,426 & 0,803 & $-0,276$ & $-0,518$ & $-0,653$ & $-0,373$ & $\mathbf{0 , 7 5 7}$ \\
\hline
\end{tabular}

Composite reliability (CR) for all scales exceed 0.7 and Average variance extracted (AVE) exceed 0.5 which is a convergent validity criteria. The criteria for discriminant validity (MSV $<$ AVE; $\mathrm{ASV}<\mathrm{AVE}$; the square root of the AVE must be higher than the correlations with another factor) are all provided (Table 4$)$.

Table 5: Results of Hypothesis Tests

\begin{tabular}{lllllll}
\hline $\begin{array}{l}\text { Independent Var- } \\
\text { iable }\end{array}$ & $\begin{array}{l}\text { Dependent } \\
\text { Variable }\end{array}$ & Estimate & S.E. & C.R. & P & Hypothesis \\
\hline Trust & Intention &, 303 &, 068 & 4,459 & $* * *$ & H1Accepted \\
Quality & Intention &, 388 &, 076 & 5,102 & $* * *$ & $\mathrm{H}_{2}$ Accepted \\
Intention & $\begin{array}{l}\text { Perceieved } \\
\text { Risk }\end{array}$ &,- 511 &, 077 & $-6,634$ & $* * *$ & H3 Accepted \\
& $\begin{array}{l}\text { Perceieved } \\
\text { Intention }\end{array}$ &, 614 &, 050 & 12,210 & $* * *$ & H4 Accepted \\
\hline
\end{tabular}

In this study, it is aimed to examine the effect of trust and service quality on mobile banking usage intention, effect of usage intention on perceived risk and benefit. Results show that, trust and service quality are positively associated with intention to use mobile banking. While intention to use has a negative effect on perceived risk, it has a positive effect on perceived benefit.

\section{Conclusion}

In recent years, due to the developments in internet technology, interest in internet banking has increased rapidly. In addition considering the developments in mobile and smart phone technologies, the adoption and use of banking services provided by the Internet is increasing day by day with the emergence of opportunities such as the fact that banking transactions can be carried out 
A. Erdem - U. Pala - M. Özkan - U. Sevim 11/4 (2019) 2384-2395

anywhere and anytime through mobile banking. Mobile banking, an extension of Internet banking, offers many advantages to users, such as time-independent processing, convenience, and cost savings.

Taking into account the increasing adoption rate of mobile banking in Turkey, it is important to investigate the usage intention factors of mobile banking. Thus, it becomes clear how Turkish customers have adopted mobile banking and how they will increase usage intention of mobile banking over time. Quality reflects the quality of information such as information relevancy, accuracy and timeliness (Kim et al, 2009) and quality of services such as ease-of-use, visual appeal etc. (Zhou, 2011).

In this research, research model includes trust, service quality, mobile banking usage intention, perceived risk and perceived benefit variables. According to literature, banking customers may be concerned about their payment security while they are using online banking system due to Trojan horses or viruses (Zhou, 2012). Also, customers pay attention on relevant information gathered from online banking system and quality of service (Kim et al, 2009; Zhou, 2011). As a result, it is predicted that both trust and service quality have an impact on intention to use mobile banking. Furthermore, it is expected that intention to use mobile banking negatively associated with perceived risk and positively associated with perceived benefit. For this purpose, associations were tested statistically and statistical results empirically approved the effects of these factors.

This study finds that trust and quality factors are highly associated with intention to use mobile banking. If banks, which offer mobile banking facilities, try to increase their number of customers, they should pay attention on their security system and improve their service quality such as easeof-use, visual appeal and information relevancy. Also, intention to use decreases the perceived risk and increases the perceived benefit. When customers have an intention to use mobile banking, their perceived risk lessens and perceived benefit increases. Intention to use mobile banking has a strong relationship with perceived benefit and perceived risk which might cause actual use of mobile banking.

For the future research, an extensive research on mobile banking can indicate the strong relationship with actual use regarding these factors. A larger scale study with a more representative sample could be conducted to validate the results of this study. With a comparison of mobile banking users and non-users, it could be better to understand the effects of these factors on actual use of mobile banking. The results of the current study are based on cross-sectional data, a longitudinal study can provide further understanding in order to indicate how much the effect of proposed factors could be stabilized or changed over time. 


\section{A. Erdem - U. Pala - M. Özkan - U. Sevim 11/4 (2019) 2384-2395 \\ References}

Akın, F. \& Karaboga,. K. (2011). Bireysel müşterilerin şubesiz bankacılık hizmetlerini kullanma kararına etki eden faktörlerin belirlenmesi üzerine bir araştırma: Bilecik örneği. Marmara Üniversitesi İIBF Dergisi, 30(1), 301-320.

Akturan, U., \& Tezcan, N. (2012). Mobile banking adoption of the youth market: Perceptions and intentions. Marketing Intelligence \& Planning, 30(4), 444-459.

Alalwan, A. A., Dwivedi, Y. K., \& Rana, N. P. (2017). Factors influencing adoption of mobile banking by Jordanian bank customers: Extending UTAUT2 with trust. International Journal of Information Management, 37(3), 99-110.

Albashrawi, M., \& Motiwalla, L. (2017). Privacy and Personalization in Continued Usage Intention of Mobile Banking: An Integrative Perspective. Information Systems Frontiers, 1-13.

Anderson, J. C., \& Gerbing, D. W. (1988). Structural equation modeling in practice: A review and recommended two-step approach. Psychological bulletin, 103(3), 411-423.

Bauer, R. A. (1960). Consumer behavior as risk taking. Risk taking and information handling in consumer behavior. Boston: Boston University Press.

Bayram, N. (2010). Yapısal eşitlik modellemesine giriş: Amos uygulamaları (1. Baskı). Bursa: Ezgi Kitabevi.

Brown, I., Cajee, Z., Davies, D., \& Stroebel, S. (2003). Cell phone banking: predictors of adoption in South Africa-an exploratory study. International Journal of Information Management, 23(5), 381-394.

Byrne, B. M. (1998). Structural equation modeling with LISREL, PRELIS, and SIMPLIS: Basic concepts, applications, and programming: New Jersey: L. Erlbaum Associates.

Çapık, C. (2014). Geçerlik ve güvenirlik çalışmalarında doğrulayıcı faktör analizinin kullanımı. Anadolu Hemşirelik ve Sağllk Bilimleri Dergisi, 17(3), 196-205.

Çokluk, Ö., Şekercioğlu, G., \& Büyüköztürk, Ş. (2010). Sosyal bilimler için çok değişkenli istatistik: SPSS ve Lisrel uygulamaları (1. Baskı). Ankara: Pegem Akademi.

Goh, T.-T., \& Sun, S. (2014). Exploring gender differences in Islamic mobile banking acceptance. Electronic Commerce Research, 14(4), 435-458.

Gu, J.-C., Lee, S.-C., \& Suh, Y.-H. (2009). Determinants of behavioral intention to mobile banking. Expert Systems with Applications, 36(9), 11605-11616.

Hanafizadeh, P., Behboudi, M., Abedini Koshksaray, A., \& Jalilvand Shirkhani Tabar, M. (2014). Mobile-banking adoption by Iranian bank clients. Telematics and Informatics, 31(1), 62-78.

Kesharwani, A., \& Singh Bisht, S. (2012). The impact of trust and perceived risk on internet banking adoption in India: An extension of technology acceptance model. International Journal of Bank Marketing, 30(4), 303-322.

Kim, G., Shin, B., \& Lee, H. G. (2009). Understanding dynamics between initial trust and usage intentions of mobile banking. Information Systems Journal, 19(3), 283-311.

Korkulu, A., Oktay, E. \& Akan, Y. (2018). Mobil bankacılık kullanımını etkileyen faktörlerin araştırılması: Atatürk üniversitesi akademik personel üzerine bir uygulama. UïID, 18. EYİ Özel Sayısı, 553-564. 
A. Erdem - U. Pala - M. Özkan - U. Sevim 11/4 (2019) 2384-2395

Kurt, K. \& Turan, A. H. (2017). Mobil bankacılık uygulamalarının benimsenmesine yönelik davranışsal niyetleri etkileyen faktörler üzerine bir araştırma. İşletme Bilimi Dergisi, 5 (3), 2558.

Laukkanen, T., \& Kiviniemi, V. (2010). The role of information in mobile banking resistance. International Journal of Bank Marketing, 28(5), 372-388.

Lin, H.-F. (2011). An empirical investigation of mobile banking adoption: The effect of innovation attributes and knowledge-based trust. International Journal of Information Management, 31(3), 252-260.

Lin, J., Wang, B., Wang, N., \& Lu, Y. (2014). Understanding the evolution of consumer trust in mobile commerce: a longitudinal study. Information Technology and Management, 15(1), 3749.

Meydan, C. H., \& Şeşen, H. (2011). Yapısal eşitlik modellemesi: AMOS uygulamaları: Detay Yayıncilik.

Munro, B. H. (2005). Statistical Methods for Health Care Research. Philadelphia: Lippincott Williams \& Wilkins.

Nakip, M. (2013). Pazarlama araştırmalarına giriş (SPSS uygulamalı) (4. Baskı ed.). İstanbul: Seçkin Yayıncilik.

Püschel, J., Mauro C. Hernandez, J., \& Afonso Mazzon, J. (2010). Mobile banking: proposition of an integrated adoption intention framework. International Journal of Bank Marketing, 28(5), 389-409.

Rios, R. E., \& Riquelme, H. E. (2010). The moderating effect of gender in the adoption of mobile banking. International Journal of Bank Marketing, 28(5), 328-341.

Shaikh, A. A., \& Karjaluoto, H. (2015). Mobile banking adoption: A literature review. Telematics and Informatics, 32(1), 129-142.

Siddhartha, D., Rik, P., \& Sanjay, F. (2011). Factors Affecting behavioral intentions towards mobile banking usage: Empirical evidence from india. Romanian Journal of Marketing, 6(1), 628.

Ullman, J. B. (2001). Structural equation modelling. In B. G. Tabachnik \& L. S. Fidell (Eds.), Using multivariate statistics. Boston: Allyn and Bacon.

Wang, J., \& Wang, X. (2012). Structural equation modeling: applications using mplus: West Sussex: Wiley \& Sons.

Wessels, L., \& Drennan, J. (2010). An investigation of consumer acceptance of M-banking. International Journal of Bank Marketing, 28(7), 547-568.

Zhou, T. (2011). An empirical examination of initial trust in mobile banking. Internet Research, 21(5), 527-540.

Zhou, T. (2012). Understanding users' initials trust in mobile banking: an elaboration likelihood perspective. Computers in Human Behavior, 28, 1518-1525. 